\title{
ENVIRONMENTAL IMPACT FROM METALURGJIK COMPLEX "TREPÇA" IN AREA OF MITROVICA
}

\author{
Skender Sallahi ${ }^{1 *}$ \\ ${ }^{1 *}$ Ministry of Economic Development, Mining Department Republic of Kosovo; \\ *Corresponding author Skender Sallahi, e-mail: skender.sallahi@ rks-gov.net;
}

Received December 2019; Accepted January 2020; Published February 2020;

DOI: https://doi.org/10.31407/ijees10.119

\begin{abstract}
During the mining and the production of the $\mathrm{Pb}-\mathrm{Zn}$ "Trepça" (Mitrovica), a considerable amount of sterile material remains after the mines flotation. This possesses a possible environmental issue and can lead to contamination of water, soil and sludge. In order to evaluate the leaching of heavy metals, the determination of lead $(\mathrm{Pb})$, zinc $(\mathrm{Zn})$, copper $(\mathrm{Cu})$, cadmium $(\mathrm{Cd})$, nickel $(\mathrm{Ni})$ and iron $(\mathrm{Fe})$ is carried out in four types of samples: water, soil, sludge and sterile material. ICP (Inductively Coupled Plasma) was used for the determination of heavy metals. The use of Principal Component Analysis (PCA), dendograms and other statistical procedures, permitted to understand the possible source of the heavy metal presence in the analyzed samples. The results obtained within this study indicate that the metal pollution in the study area is strongly influenced by the Trepça complex. The results presented here can serve national agencies to take measures regarding the monitoring programs for heavy metals.
\end{abstract}

Keywords: heavy metals, flotation process, sludge, water, soil, 'Trepça' complex. 